\title{
Incidence of cancer among workers in a Norwegian nitrate fertiliser plant
}

\author{
Stein Inge Fandrem, Helge Kjuus, Aage Andersen, Even Amlie
}

\begin{abstract}
The incidence of cancer among 2023 male fertiliser workers has been investigated in a historical cohort study. Workers who had been employed for more than one year in work with possible exposure to dust containing nitrate between 1945 and 1979 were included. An individual cumulated exposure to dust expressed in level-years was calculated for each participant. The cohort was followed up from 1953 to the end of 1988, and the incidence of cancer was compared with the national rates. There were 467 deaths $v 504.8$ expected (standardised mortality ratio $(S M R)=0.93)$, and 185 cases of cancer $v 195.5$ expected (standardised incidence ratio $(S I R)=0.95)$. Thirty cases of lung cancer were found $v 27.5$ expected (SIR = 1.09). No overall excess of gastric cancer was found (15 cases $v 17 \cdot 0$ expected; SIR $=0.89$ ). No association was found between cumulated exposure to nitrate and gastric cancer, and there was no association between duration of employment or time since first employment and incidence of gastric cancer.
\end{abstract}

(British fournal of Industrial Medicine 1993;50:647-652)

Carcinogenic $\mathrm{N}$-nitroso compounds may be formed endogenously in humans. Exogenous nitrate is resorbed in the gastrointestinal tract, and partially secreted into the saliva where some nitrate is reduced to nitrite by bacteria. Nitrite may react with a secondary nitrogen group in substances that occur in food and drugs to form $\mathrm{N}$-nitroso compounds. It has thus been postulated that subjects

Department of Occupational Medicine, Telemark Central Hospital, Porsgrunn, Norway

SI Fandrem, $\mathrm{H}$ Kjuus

Cancer Registry of Norway, Oslo, Norway

A Andersen

Health Department, Hydro Porsgrunn, Porsgrunn, Norway

E Amlie ingesting large amounts of nitrate may run an increased risk of gastric cancer. ${ }^{1}$ Different epidemiological studies have given inconsistent results, showing association as well as lack of association between exposure to nitrate and gastric cancer. ${ }^{2-9}$

In Norway $85 \%$ of the population is supplied with surface waters that contain very low nitrate concentrations (about $2 \mathrm{mg} \mathrm{NO}_{3} / 1$ ), and exposure to nitrate in the general population, estimated to be $31.4 \mathrm{mg} /$ day in 1980 , occurs mainly from vegetables and is thus associated with consumption of nitrite scavengers (ascorbate and retinols). ${ }^{10}$ Work related exposure to airborne nitrate is without simultaneous consumption of these scavengers, however, and may be prolonged and higher than exposure from food consumption. Exposure to nitrate by inhalation during fertiliser production could thus generate more endogenous nitrosation than nitrates from food. Two cohort studies among British fertiliser workers did not show any excess of gastric cancer, ${ }^{11-13}$ and studies in Iceland and Sweden gave comparable results. ${ }^{1415}$ To further investigate whether exposure to airborne nitrate is associated with increased risk of gastric cancer and lung cancer, we have studied the incidence of cancer in a cohort of fertiliser workers over a long follow up period. These workers have been employed at the largest fertiliser plant in Norway.

\section{Study plants and exposure}

The study plants are situated in south east Norway in an industrial complex that also comprises production plants for ammonia, nitric acid, magnesium, and polyvinyl chloride.

The company has produced calcium nitrate fertilisers since 1929 in one plant and complex fertilisers since 1936 in another plant. A second complex fertiliser plant was started in 1967. Complex fertilisers are produced from raw phosphate, nitric acid, ammonia, and potassium compounds. Rasorite, pentahydrate-borax, kieserite, cuprosulphate, and waste copper may be supplied. From 1969 amorphous silica has been used as a conditioner. Kieselguhr and calcium stearate were used before that. Calcium nitrate fertilisers are produced from spill off from the complex fertiliser plants, 
Table 1 Environmental measurements of dust containing nitrate in various plants and departments during the period 1966-87

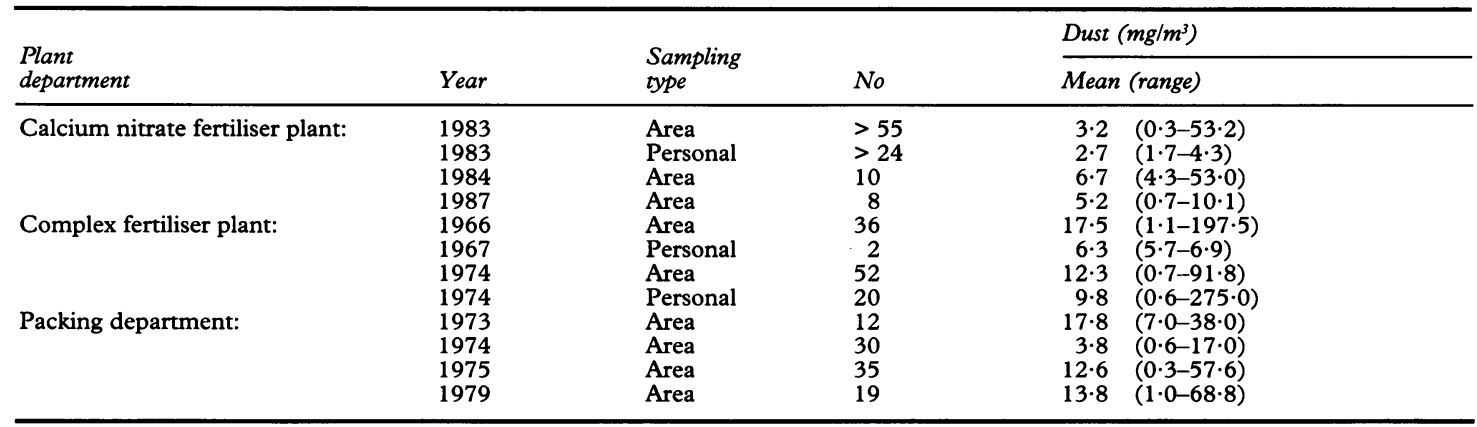

nitric acid, and ammonia. Rasorite or pentahydrate-borax may be added, but no conditioner is used. Calcium nitrate fertilisers were historically produced from local limestone, nitric acid, and ammonia. The nitrate content in complex fertilisers was $25.2 \%$ when the plant was restarted after the second world war, in 1945, and was gradually raised to an average of $40.3 \%$ in 1988 . Calcium nitrate fertilisers have contained $64.0 \%$ nitrate since the production was started in 1929.

\section{EXPOSURE ESTIMATES}

Measurements of dust containing nitrate in the working environment have been carried out from 1967 onwards, and table 1 summarises the results. In the complex fertiliser plants the concentrations of dust containing nitrate in the $1960 \mathrm{~s}$ and the 1970 s were from 6 to $17 \mathrm{mg} / \mathrm{m}^{3}$. The dust concentrations in the packing department were up to $18 \mathrm{mg} / \mathrm{m}^{3}$ during the $1970 \mathrm{~s}$. Measurements in the calcium nitrate fertiliser plant in the 1980 s showed dust concentrations from 3 to $7 \mathrm{mg} / \mathrm{m}^{3}$.

Based on these measurements and information on changes in production methods as well as interviews with some veterans, a job exposure matrix was constructed for exposure to nitrate (figure). This matrix comprised four levels of dust containing nitrate dust for each department. Based on this matrix individual cumulated exposures to nitrate, expressed in level-years, were calculated by multiplying duration of each employment period with the estimated historical level of exposure and adding up these results for all employment periods for every employee.

\section{SMOKING HABITS}

Surveys on smoking habits among the employees from the whole industrial complex were conducted in 1962 and 1980 . In $196271 \%$ of 500 randomly selected employees were daily smokers, and in 1980 $49 \%$ of all 4307 employees were daily smokers. Corresponding figures for male Norwegians were
$63 \%$ and $42 \%$ in 1962 and 1980 respectively (Løchsen et al, unpublished data).

\section{Subjects and methods}

One personnel department has served all the plants in the industrial complex since 1929 and one health department since 1938. The records at these two departments were the sources of information about each worker. The individual records at the health department contained name, date of birth, five digit personal number (for employees working after 1960), dates for start and end of employment and a short work history. These records were complete from 1945 onwards for name, date of birth, and dates for start and termination of work for all

\begin{tabular}{|c|c|c|}
\hline & Year & \\
\hline 194 & 1966 & 1980 \\
\hline
\end{tabular}

Calcium-nitrate plant/ Complex fertiliser plants

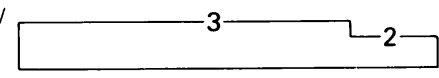

All management departments

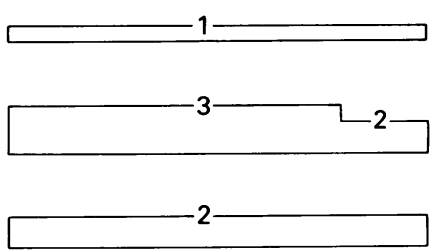

Packing

department

Quay

Storehouse

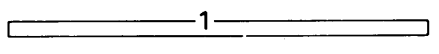

Packing, quay, and storehouse/ maintenance department

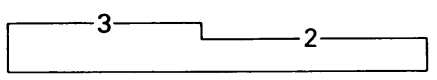

Estimated levels (0-3) of exposure to dust containing nitrate in different departments in the period 1945-88. Level 0 none; level 1 little; level 2 moderate, usually $<10 \mathrm{mg} / \mathrm{m}^{3}$; level 3 considerable, often $>10 \mathrm{mg} / \mathrm{m}^{3}$. 
Table 2 Distribution of date of first employment and number of years of employment within the study cohort of 2023 nitrate fertiliser workers

\begin{tabular}{ll}
\hline Date of first employment & No (\%) \\
\hline $1945-9$ & $280(13 \cdot 9)$ \\
$1950-9$ & $763(37 \cdot 7)$ \\
$1960-9$ & $634(31 \cdot 3)$ \\
$1970-9$ & $346(17 \cdot 1)$ \\
No of years of employment: & $393(19 \cdot 4)$ \\
$<2$ & $432(21 \cdot 4)$ \\
$2-4$ & $304(15 \cdot 0)$ \\
$5-9$ & $894(44 \cdot 2)$ \\
\hline 10 & \\
\hline
\end{tabular}

employees with more than one year of permanent employment. The records at the personnel department contained name, date of birth, places of work, and dates for commencement and interception for each period of employment in the different plants and departments of the company. This register was incomplete because old records were occasionally discarded in the 1970s. Out of 30334 previous or present employees registered in these files covering the period 1929 to 1989,5718 employees lacked work histories in the records of the personnel department. These work histories were reconstructed from information in the medical records and this was successful for 5660 employees.

In this study, all male workers were included who had been employed for the first time between 1 January 1945 and 31 December 1979 and employed for at least one year in the calcium nitrate plant, the complex fertiliser plants, or related departments. The inclusion criteria were met by 2023 employees, and 1990 of these were identified by birth and unique personal numbers given to all Norwegian citizens alive in 1960 or born later. Thirty three men had died or had emigrated before 1960, but all these were identified manually. Thus all employees who met the inclusion criteria were identified and included in the cohort. Table 2 shows the distribution of date of first employment and number of years of employment.

Beyond information on department of work or area of work, the records at the health department and the personnel department were incomplete for job titles of the individual workers. Therefore, job titles were not used for further characterisation of the cohort.

The occurrence of cancer in the cohort was recorded from 1 January 1953 to 31 December 1988. Each member of the cohort was followed up from 1953 or, if first employed at a later date, from the middle of the year he was first employed, until death, emigration, or the end of 1988. Fifteen employees had emigrated after 1 January 1953 and were followed up to the middle of the year of emigration. The cases of cancer were identified through the Cancer Registry of Norway which has recorded all new cases of cancer in the whole Norwegian population since 1 January 1953. The observed incidences of selected cancers were compared with the age adjusted incidences of cancer in the national male population with the use of five year age specific incidence rates for each year from 1953 to 1988.

Several employees had held jobs in different departments during their employment. Calculations on the incidences of cancer among workers in the different departments were made with each department being viewed as a separate entity. Thus one worker may have contributed an observed cancer case to more than one department, but only once in the total cohort.

On the assumption of a Poisson distribution of the observed cases, 95\% confidence intervals $(95 \%$ CIs) were estimated with a two sided test of significance.

\section{Results}

There were 467 deaths from all causes in the cohort $v 504.8$ expected (standardised mortality ratio $(\mathrm{SMR})=0.93$ ) and 185 cases of cancer $v$ 195.5 expected (standardised incidence ratio (SIR) $=0.95$ ) (table 3).

Fifteen cases of gastric cancer were observed $v$

Table 3 Observed $(O)$ and expected $(E)$ new cases of cancer at selected sites among 2023 male nitrate fertiliser workers employed for the first time between Fanuary 1945 and December 1979

\begin{tabular}{|c|c|c|c|c|}
\hline Cancer site (ICD-7) & $O$ & $E$ & $S I R$ & $(95 \% C I)$ \\
\hline $\begin{array}{l}\text { Oesophagus (150) } \\
\text { Stomach (151) } \\
\text { Colon/rectum (153-154) } \\
\text { Lung (162) } \\
\text { Pleura (163) } \\
\text { Kidney (180) } \\
\text { Bladder (181) } \\
\text { Pancreas (157) } \\
\text { Malignant melanoma (190) } \\
\text { All cancers (140-207) }\end{array}$ & $\begin{array}{r}1 \\
15 \\
23 \\
30 \\
0 \\
9 \\
13 \\
9 \\
5 \\
185\end{array}$ & $\begin{array}{r}2 \cdot 4 \\
17 \cdot 0 \\
26 \cdot 0 \\
27 \cdot 5 \\
0 \cdot 7 \\
7 \cdot 6 \\
13 \cdot 5 \\
7 \cdot 3 \\
6 \cdot 4 \\
195 \cdot 5\end{array}$ & $\begin{array}{l}0.42 \\
0.89 \\
0.88 \\
1.09 \\
1 \cdot 18 \\
0.96 \\
1 \cdot 23 \\
0.78 \\
0.95\end{array}$ & $\begin{array}{l}\overline{0.49}-1.45 \\
0.56-1.33 \\
0.73-1.53 \\
- \\
0.54-2.25 \\
0.51-1.64 \\
0.56-2.34 \\
0.25-1.83 \\
0.81-1.09\end{array}$ \\
\hline
\end{tabular}

ICD-7 = Code of the International Classification of Diseases (7th revision).

Follow up period 1953-88; in total 50966 observation-years. 
Table 4 Observed (O) and (E) expected cases of new cancer among 2023 nitrate fertiliser workers by place of work

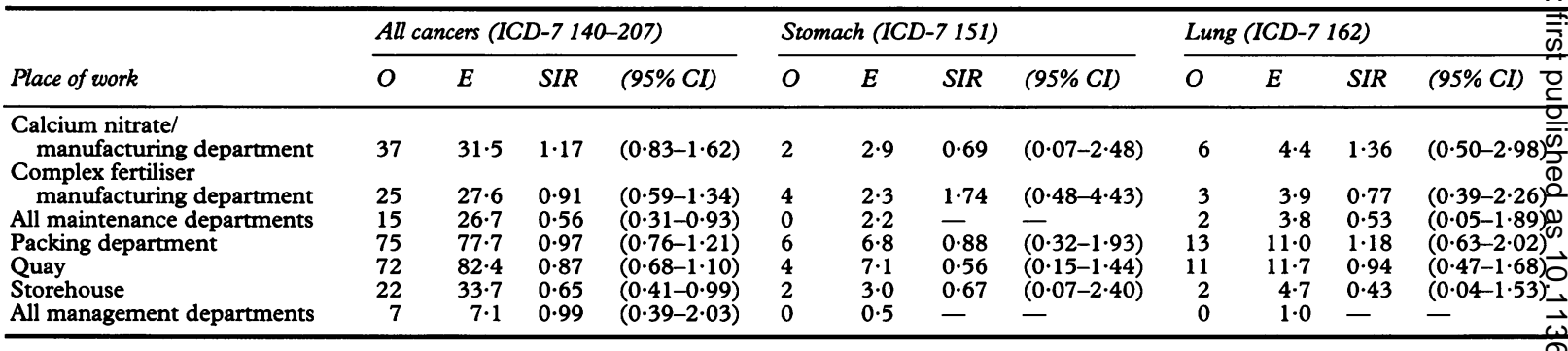

Table 5 Observed $(O)$ and expected $(E)$ cases of new cancer among 2023 nitrate fertiliser workers by estimated cumulative nitrate exposure $\frac{\mathbb{D}}{3}$

\begin{tabular}{|c|c|c|c|c|c|c|c|c|c|c|c|c|}
\hline \multirow[b]{2}{*}{ Nitrate index (level-years) } & \multicolumn{4}{|c|}{ All cancers (ICD-7 140-207) } & \multicolumn{4}{|c|}{ Stomach (ICD-7 151) } & \multicolumn{4}{|c|}{ Lung (ICD-7 162) } \\
\hline & $O$ & $E$ & $S I R$ & $(95 \% C I)$ & $O$ & $E$ & $S I R$ & $(95 \% C I)$ & $O$ & $E$ & $S I R$ & $(95 \% C I)$ \\
\hline $\begin{array}{l}01-19 \\
20-39 \\
4-59 \\
\geqslant 60\end{array}$ & $\begin{array}{l}75 \\
45 \\
25 \\
40\end{array}$ & $\begin{array}{l}85 \cdot 0 \\
39 \cdot 8 \\
30 \cdot 7 \\
40 \cdot 0\end{array}$ & $\begin{array}{l}0.88 \\
1 \cdot 13 \\
0.81 \\
1.00\end{array}$ & $\begin{array}{l}(0 \cdot 72-1 \cdot 13) \\
(0.82-1 \cdot 51) \\
(0.53-1 \cdot 21) \\
(0.72-1 \cdot 36)\end{array}$ & $\begin{array}{l}6 \\
3 \\
3 \\
3\end{array}$ & $\begin{array}{l}7 \cdot 1 \\
3 \cdot 6 \\
2 \cdot 8 \\
3 \cdot 5\end{array}$ & $\begin{array}{l}0.85 \\
0.83 \\
1.07 \\
0.88\end{array}$ & $\begin{array}{l}(0 \cdot 31-1 \cdot 85) \\
(0 \cdot 17-2 \cdot 44) \\
(0 \cdot 21-3 \cdot 14) \\
(0 \cdot 17-2 \cdot 51)\end{array}$ & $\begin{array}{r}14 \\
5 \\
5 \\
6\end{array}$ & $\begin{array}{r}11 \cdot 8 \\
5 \cdot 5 \\
4 \cdot 3 \\
5 \cdot 9\end{array}$ & $\begin{array}{l}1 \cdot 19 \\
0.91 \\
1 \cdot 16 \\
1.02\end{array}$ & $\begin{array}{l}(0.65-1.99) \\
(0.29-2.13) \\
(0.37-2.72) \\
(0.37-2.22)\end{array}$ \\
\hline
\end{tabular}

$17 \cdot 0$ expected, and 23 cases of colon or rectum cancer $v 26.0$ expected. There were 30 cases of lung cancer $v 27.5$ expected $(\operatorname{SIR}=1.09)$. No pleural mesothelioma was found.

Dividing the cohort by place of work did not show any significant excess of total cancer among workers in any department (table 4). There were significantly less cancers than expected among maintenance workers. Four cases of gastric cancer $v 2.3$ expected were observed among employees in the manufacturing departments of the complex fertiliser plants. There were fewer cases of gastric cancer than expected among workers in the other departments. Six cases of lung cancer were observed $v 4.4$ expected among workers in the manufacturing department of the calcium nitrate fertiliser plant, and 13 cases $v 11.0$ expected among workers in the packing department. Cancer of the colon, rectum, kidney, and bladder were not in excess among workers in any department.

The incidence of total cancers was not increased in groups with the highest cumulated exposure to dust (table 5). Six cases of gastric cancer were observed $v 7 \cdot 1$ expected in the group with the lowest nitrate index and three cases $v 3.5$ expected in the group with the highest index. Similarly, no associations between the applied nitrate index and the incidence of cancer of the lung, colon, rectum, kidney, and bladder were found.

Table 6 shows the incidence of selected cancers by duration of employment. The incidence of gastric cancer was not higher for employees with more than 25 years of employment compared with employees with less than five years of employment.

To allow for development time for cancer, analyses were performed according to time since first employment (table 7). After a latency period of more than 20 years there was no excess of gastric cancer (6 observed $v \quad 10 \cdot 2$ expected) and there were 25 cases of lung cancer $v 19.3$ expected. This difference was not significant.

\section{Discussion}

The present results accord with the results of Fraser et $a l^{213}$ and Al-Dabbagh et al, ${ }^{11}$ which showed no excess of gastric cancer among British fertiliser workers. Workers exposed to an average airborne nitrate concentration of $10 \mathrm{mg} / \mathrm{m}^{3}$ were characterised as heavily exposed by Al-Dabbagh et al. ${ }^{11}$ In the present study the average historical concentration of nitrate in the working atmosphere was

Table 6 Observed (O) and expected (E) cases of new cancer among 2023 nitrate fertiliser workers by years of employment

\begin{tabular}{|c|c|c|c|c|c|c|c|c|c|c|c|c|}
\hline \multirow[b]{2}{*}{ Years of employment } & \multicolumn{4}{|c|}{ All cancers (ICD-7 140-207) } & \multicolumn{4}{|c|}{ Stomach (ICD-7 151) } & \multicolumn{4}{|c|}{ Lung (ICD-7 162) } \\
\hline & $O$ & $E$ & SIR & $(95 \% C I)$ & $O$ & $E$ & SIR & $(95 \% C I)$ & $O$ & $E$ & SIR & $(95 \% C I)$ \\
\hline $\begin{array}{l}01-04 \\
05-14 \\
15-24 \\
\geqslant 25\end{array}$ & $\begin{array}{l}54 \\
56 \\
46 \\
29\end{array}$ & $\begin{array}{l}62 \cdot 0 \\
58 \cdot 6 \\
50 \cdot 6 \\
24 \cdot 8\end{array}$ & $\begin{array}{l}0.87 \\
0.96 \\
0.91 \\
1.17\end{array}$ & $\begin{array}{l}(0.65-1 \cdot 14) \\
(0.72-1 \cdot 24) \\
(0.67-1.21) \\
(0.78-1.68)\end{array}$ & $\begin{array}{l}6 \\
4 \\
3 \\
2\end{array}$ & $\begin{array}{l}5 \cdot 3 \\
5 \cdot 7 \\
4 \cdot 4 \\
1 \cdot 7\end{array}$ & $\begin{array}{l}1 \cdot 13 \\
0 \cdot 70 \\
0 \cdot 68 \\
1 \cdot 18\end{array}$ & $\begin{array}{l}(0.42-2 \cdot 47) \\
(0.19-1 \cdot 79) \\
(0.14-2 \cdot 00) \\
(0.12-4.24)\end{array}$ & $\begin{array}{r}10 \\
9 \\
4 \\
7\end{array}$ & $\begin{array}{l}8 \cdot 5 \\
8 \cdot 0 \\
7 \cdot 1 \\
4 \cdot 0\end{array}$ & $\begin{array}{l}1 \cdot 18 \\
1 \cdot 13 \\
0.56 \\
1.75\end{array}$ & $\begin{array}{l}(0.56-2 \cdot 16 \\
(0.46-2 \cdot 14 \\
(0.15-1.44 \\
(0.70-3.60\end{array}$ \\
\hline
\end{tabular}


Table 7 Observed $(O)$ and expected $(E)$ cases of new cancer among 2023 nitrate fertiliser workers by years since first employment

\begin{tabular}{|c|c|c|c|c|c|c|c|c|c|c|c|c|}
\hline \multirow[b]{2}{*}{ Years since first employment } & \multicolumn{4}{|c|}{ All cancers (ICD-7 140-207) } & \multicolumn{4}{|c|}{ Stomach (ICD-7 151) } & \multicolumn{4}{|c|}{ Lung (ICD-7 162) } \\
\hline & $O$ & $E$ & SIR & $(95 \% C I)$ & $O$ & $E$ & SIR & $(95 \% C I)$ & $O$ & $E$ & SIR & $(95 \% C I)$ \\
\hline $\begin{array}{l}01-09 \\
10-19 \\
20-29 \\
\geqslant 30\end{array}$ & $\begin{array}{l}13 \\
41 \\
59 \\
72\end{array}$ & $\begin{array}{l}18 \cdot 8 \\
45 \cdot 3 \\
70 \cdot 5 \\
61 \cdot 4\end{array}$ & $\begin{array}{l}0.69 \\
0.91 \\
0.84 \\
1.17\end{array}$ & $\begin{array}{l}(0.37-1 \cdot 18) \\
(0 \cdot 65-1 \cdot 23) \\
(0.64-1 \cdot 08) \\
(0.92-1 \cdot 48)\end{array}$ & $\begin{array}{l}2 \\
7 \\
3 \\
3\end{array}$ & $\begin{array}{l}2 \cdot 2 \\
4 \cdot 7 \\
5 \cdot 9 \\
4 \cdot 3\end{array}$ & $\begin{array}{l}0.91 \\
1.49 \\
0.51 \\
0.70\end{array}$ & $\begin{array}{l}(0.09-3.27) \\
(0.60-3.06) \\
(0.10-1.49) \\
(0.14-2.04)\end{array}$ & $\begin{array}{r}2 \\
3 \\
12 \\
13\end{array}$ & $\begin{array}{r}2 \cdot 0 \\
6 \cdot 2 \\
10 \cdot 3 \\
9 \cdot 0\end{array}$ & $\begin{array}{l}1.00 \\
0.48 \\
1 \cdot 17 \\
1.44\end{array}$ & $\begin{array}{l}(0 \cdot 10-3 \cdot 60) \\
(0 \cdot 10-1 \cdot 42) \\
(0 \cdot 60-2 \cdot 04) \\
(0 \cdot 77-2 \cdot 47)\end{array}$ \\
\hline
\end{tabular}

estimated to be about $10 \mathrm{mg} / \mathrm{m}^{3}$, which is higher than estimated in the study by Hagmar et al. ${ }^{15}$ Rafnsson $e t \mathrm{al}^{14}$ indicated exposure to higher concentrations of dust containing nitrate than the Swedish study, but there was no excess of gastric cancer in the Icelandic cohort.

The records of the personnel department and the medical department were the sources of information on each worker. The work histories constructed from the available information in the records of the health department were considered to be complete with the exception of shorter periods when some employees may have been hired by other departments.

The health department has existed since 1938 and health examinations before employment in the 1940 s and 1950s may have resulted in selection of members to the cohort at its inception, which could have concealed possible positive associations between work related exposure and illness. ${ }^{16}$ The impact on the incidence of cancer in general, however, from this possible selection as an aspect of the healthy worker effect is assumed to be limited. ${ }^{17}$ Chronic atrophic gastritis may be associated with gastric cancer, ${ }^{18}$ but we did not find individual records where gastritis was diagnosed at the preemployment health examination and used as refusal of employment. To minimise selection through attrition of the population as another aspect of the healthy worker effect, and heterogeneous exposure before inclusion, we chose an inception cohort design as proposed by Weiss. ${ }^{19}$

Neither the records at the health department nor those at the personnel department had complete individual data on job titles of each worker, which may have resulted in loss of some small subgroups of workers with higher exposure to dust containing nitrate.

The incidence of cancers of concern in the county where the industrial complex is situated are close to the national rates, and the national rates were used as the reference entity. Age standardised incidence of gastric cancer for men in the period 1970-9 was 20.4 per 100000 in the county and 20.7 in Norway. The corresponding figures for lung cancer were 22.0 in the county and 25.2 in Norway.

The British studies ${ }^{11-13}$ indicated a slight excess of lung cancer in some subgroups. That found in the present study may be due to chance. A higher prevalence of smoking in the index group compared with the reference population may also contribute to the excess. Interviewed veteran workers considered the exposure to asbestos dust in the study plant to be sporadic or low. Asbestos exposure in other plants in this industrial complex (a magnesium plant and an electrochemical plant) has been prevalent and an increased incidence of lung cancer has been found. ${ }^{2021}$ Information on exposure to asbestos in these and other plants before or after employment in the fertiliser plants was lacking for workers included in the cohort. The absence of pleural mesotheliomas in the study cohort is in accord with the view that exposure to asbestos may not have contributed much to the occurrence of lung cancers.

In summary, the present results do not support the hypothesis of increased risk of gastric cancer among fertiliser workers exposed to nitrate.

The study was carried out with financial support from Hydro Porsgrunn, Porsgrunn, Norway.

Requests for reprints to: Stein Inge Fandrem, Department of Occupational Medicine, Telemark Central Hospital, N-3900 Porsgrunn, Norway.

1 Mirvish SS. The etiology of gastric cancer, intragastric nitrosamide formation and other theories. I Natl Cancer Inst 1983;71:631-47.

2 Zaldivar R, Robinson $H$. Epidemiological investigation on stomach cancer mortality in Chileans: association with nitrate fertilizer. $Z$ Krebsforsch 1973;80:289-95.

3 Armijo R, Coulson AH. Epidemiology of stomach cancer in Chile-the role of nitrogen fertilizers. Int $\mathcal{F}$ Epidemiol 1975; 4:301-9.

4 Armijo R, Gonzales A, Orellana M, Coulson AH, Sayre JW, Detels R. Epidemiology of stomach cancer in Chile: II nitrate exposure and stomach cancer frequency. Int $\mathcal{f}$ Epidemiol 1981;10:57-62.

5 Correa P, Cuello C, Duque E. Carcinoma and intestinal metaplasia of the stomach in Colombian migrants. $\mathcal{F}$ Natl Cancer Inst 1970;44:297-306.

6 Haenszel W, Correa P, Cuelloo C, et al. Gastric cancer in Colombia II. Case control epidemiologic study of precursor lesions. ₹ Natl Cancer Inst 1976;57:1021-26.

7 Cuello C, Correa P, Haenszel W, et al. Gastric cancer in Colombia I. Cancer risk and suspected environmental agents. I Natl Cancer Inst 1976;57:1015-20.

8 Correa P, Cuello C, Fajardo LF, Haenszel W, Bolanos O, Ramirez B. Diet and gastric cancer: nutrition survey in a high-risk area. $\mathcal{F}$ Natl Cancer Inst 1983;70:673-8. 
9 Hill MJ, Hawksworth GM, Tattersall G. Bacteria, nitrosamines and cancer of the stomach. B $f$ Cancer 1973; 28:562-7.

10 Technical Report No 27 (1988), ECETOC, Brussels, Belgium.

11 Al-Dabbagh S, Foreman D, Bryson D, Stratton I, Doll R. Mortality of nitrate fertiliser workers. B F Ind Med 1986; 43:507-15.

12 Fraser P, Chilvers C, Goldblatt P. Census-based mortality study of fertiliser manufacturers. $B \mathcal{F}$ Ind Med 1982;39: 323-9.

13 Fraser P. Chilvers C, Day M, Goldblatt P. Further results from a census based mortality study of fertiliser manufacturers. $B \mathcal{F}$ Ind Med 1989;46:38-42.

14 Rafnsson V, Gunnarsdóttir H. Mortality study of fertiliser manufacturers in Iceland. $B \mathcal{F}$ Ind Med 1990;47:721-5.

15 Hagmar L, Bellander T, Andersson C, et al. Cancer morbidity in nitrate fertilizer workers. Inst Arch Occup Environ Health 1991;63:63-7A.

16 Miettinen OS. Comparability of populations. In: Theoretical epidemiology. New York: John Wiley 1985:31-4.
17 McMichael AJ. Standardised mortality ratios and the healthy worker effect: scratching beneath the surface. $F$ Occup Med 1976;18:165-8.

18 Haenszel W, Correa P, Cuello C, Guzman N, Burbano LC, Lores H, Muñoz J. Gastric cancer in Colombia II. Casecontrol epidemiologic study of precursor lesions. $f$ Natl Cancer Inst 1976;57:1021-6.

19 Weiss W. Heterogeneity in historical cohort studies: a source of bias in assessing lung cancer risk. $\mathcal{F}$ Occup Med 1983;25:290-4.

20 Hilt $\mathrm{B}$, Langård S, Andersen A, Rosenberg J. Asbestos exposure, smoking habits, and cancer incidence among production and maintenance workers in an electrochemical plant. Am f Ind Med 1985;8:565-77.

21 Heldaas S. Langård S, Andersen A. Incidence of cancer in a cohort of magnesium production workers. B f Ind Med 1989;46:617-23.

Accepted 28 September 1992

\section{Vancouver style}

All manuscripts submitted to the $\mathrm{Br} \mathcal{F}$ Ind $\mathrm{Med}$ should conform to the uniform requirements for manuscripts submitted to biomedical journals (known as the Vancouver style.)

The $\mathrm{Br} \mathcal{F}$ Ind $\mathrm{Med}$, together with many other international biomedical journals, has agreed to accept articles prepared in accordance with the Vancouver style. The style (described in full in $\mathrm{Br}$ Med $\mathcal{F}, 24$ February 1979, p 532) is intended to standardise requirements for authors.

References should be numbered consecutively in the order in which they are first mentioned in the text by Arabic numerals above the line on each occasion the reference is cited (Manson ${ }^{1}$ confirmed other reports ${ }^{2-5} \ldots$ ). In future references to papers submitted to the $B r \mathcal{F}$ Ind Med should include: the names of all authors if there are six or less or, if there are more, the first three followed by et al; the title of journal articles or book chapters; the titles of journals abbreviated according to the style of Index Medicus; and the first and final page numbers of the article or chapter.

Examples of common forms of references are:

1 International Steering Committee of Medical Editors, Uniform requirements for manuscripts submitted to biomedical journals. Brf Ind Med 1979;1:532-5.

2 Soter NA, Wasserman SI, Austen KF. Cold urticaria: release into the circulation of histamine and eosino-phil chemotactic factor of anaphylaxis during cold challenge. $N$ Engl f Med 1976;294:687-90.

3 Weinstein L, Swartz MN. Pathogenic properties of invading micro-organisms. In: Soderman WA Jr, Soderman WA, eds. Pathologic physiology, mechanisms of disease. Philadelphia: W B Saunders, 1974:457-72. 